\title{
Türkiye'de Okul Öncesi Eğitimde Dil Gelişimi Alanında Yapılan Lisansüstü Tezlerin İncelenmesi
}

\author{
Rahime Filiz KIREMiT*
}

Türkiye'de Okul Öncesi Eğitimde Dil Gelişimi Alanında Yapılan Lisansüstü Tezlerin İncelenmesi

Özet

Bu çalışmanın amacı, sekizinci sınıf öğrencilerinin, PISA 2003 matematik sınavı soruları ve değerlendirmeleri esas alınarak; matematik okuryazarlık düzeyini belirlemektir. Çalışmada ayrıca sekizinci sınıf öğrencilerinin matematik okuryazarlık düzeylerine dağıımlarının cinsiyet, okul öncesi eğitim, aile aylık gelir durumu ve anne-baba eğitim durumu değişkenleri ile ilişkisi araştırılmıştır. Araştırmada tarama modeli kullanıımıştır. Araştırmanın çalışma grubunu, Eskişehir il merkezinde bulunan 12 ilköğretim okulunun sekizinci sınıfında öğrenim gören öğrenciler arasından rastlantısal olarak seçilen 1047 öğrenci oluşturmaktadır. Araştırmanın verileri, araştırmacı tarafından Türkçeye çevrilen PISA 2003 matematik soruları ile kişisel bilgi formu yardımıla Eskişehir il merkezinde bulunan 12 ilköğretim okulunun sekizinci sınıfında öğrenim gören öğrenciler arasından rastlantısal olarak seçilen 1047 öğrenci oluşturmaktadır. Araştırmanın verileri, araştırmacı tarafından Türkçeye çevrilen PISA 2003 matematik soruları ile kişisel bilgi formu yardımıyla toplanmıştır.

Anahtar Kelimeler: : Dil Gelişimi, Okul Öncesi, Yüksek Lisans Ve Doktora Tezleri
An Overview Of Postgraduate Theses Within The Field Of Language Development At Early Childhood Education in Turkey

\section{Abstract}

This study aims to investigate postgraduate theses that have been made in the field of language development in pre-school education in Turkey between 2000 and 2018. The population of the study was comprised of 29 master's theses and 6 doctorate theses, a total of 35 theses. By making content analysis, theses were analyzed to include the aspect such as distribution by year, city, university, language, department, samplings, its subject, method and data analysis method. The obtained data was interpreted in a manner based on the percentage and frequency. According the result of the research, it is seen that there are a few studies in doctoral theses, children are the most chosen participant group, the effect of the education programs on children's language development has been found as the most studied subject in the field of language development.

Key Words: Language Development, Master's and Doctoral Theses, Pre-School Education

\section{Giriş}

Dil duygu ve düşüncelerin aktarımını sağlamak ve bireyler arası iletişimi sağlamak amacıyla anlamlı sözcüklerin bir araya getirilmesidir (Temel, Bekir \& Yazıcı, 2014). Dil gelişimi doğumla başlayan ve hayat boyu devam eden bir gelişim sürecidir (MEGEP, 2007). Hayatının her döneminde, her

\footnotetext{
*Rahime Filiz KIREMiT, Arş. Gör.,Necmettin Erbakan Üniversitesi, Eğitim Fakültesi, filizkiremit@gmail.com ; ORCID ID orcid.org/0000-0003-2418-1515
} 
Rahime Filiz KIREMiT

alanındaki kazanımların temeli dil becerileriyle atılmaktadır. Dil öğrenmek için gerekli olan donanımların büyük bir bölümü bebeklik döneminde gelişmektedir (Temel, 2009). Bebeklik döneminde başlayan dil edinimi 12 yaşına kadar devam etmektedir (Çelebi, 2006). Dil edinimi açısından kritik dönemler bulunmaktadır ve bu kritik dönemlerde çocukların çevreleriyle yeterince iletişime girmemeleri durumunda sorunlar ortaya çıkmaktadır (Demirezen, 2003). Huber (2007)'a göre de dil edinimi doğumla başlamakta ve 3 yaşına kadar devam etmektedir. Bu dönemde yeterince dil girdisi almayan çocukların dili edinmekte zorluklarla karşılaştıkları görülmektedir. Çocuklar çevrelerinde konuşulan dilleri kendilerine girdi olarak kabul etmekte ve karşııklı konuşma içerisinde olmasalar bile dili öğrenebilmektedirler (McDevitt \& Ormrod, 2013). Bu yüzden bebeklik döneminde çocukların yeterince dil girdisi almaları gerekmektedir. Belirli bir süreç sonrasında kazanılan dil, insanın yaşamı boyunca kullanabileceği bir donanım haline gelmektedir. Küçük yaştaki çocukların dili öğrenmelerinin en önemli sebebi, çevrelerindeki doğal dilin varlığıdır (Marsh, 2012). Dil kullanımı bireylerin sosyal ve bilişsel gelişimi açısından gerekli görülmektedir (Özbay ve Melanlıoğlu, 2008). Dil kullanımında kelime hazinesinin gelişmiş olması gerekmektedir. Kelime hazinesinin gelişmiş olması anadilinin ve ona bağlı olan konuşma, dinleme, okuma ve yazma becerilerinin de gelişmiş olması demektir (Karatay, 2007).

Yapılan çalışmalar sonucunda ailelerin çocukları ile etkileşim halinde bulunmalarının çocukların dil gelişimlerine etkisi olduğu ortaya çıkmıştır (Bitetti \& Scheffner Hammer, 2016; Lee, Choi \& Marques-Pascual, 2016). Çocukların dil gelişimlerinin desteklenmesi sürecinde ailelerin çocukları için gerekli uyarııları sunmaları gerekmektedir (Ayrancı, 2018). Aileler çocukların dil gelişimlerinde önemli bir rol oynamaktadır (Morrison, 2015). Çocukların dil becerilerinin gelişmesi için kullanılacak yöntemlerden bir tanesi oyundur. Çocukların oyun içerisinde karşılıkı etkileşim halinde olmalarının sağlanması gerekmektedir (Yazıcı ve Dereobalı, 2015). Okul öncesi eğitim programı incelendiğinde dil gelişimi ile ilgili olan kazanımlardan bir tanesinin çocukların duygu ve düşüncelerini söyleyebilecekleri ortamlar yaratılmaları gerektiğidir (MEB, 2013). Öğretmenlerin çocukların konuşmalarını desteklemeleri ve hikaye okumak, şarkı söylemek ve müzik dinlemek gibi etkinliklerle çocukların iletişim kurmalarını sağlamaları gerekmektedir (Morrison, 2015). Okul öncesi dönemde dil gelişiminin desteklenmesi için öğretmenlerin çocukları okuma yazmaya motive etmeleri, onların gelişim düzeylerine uygun farklı yöntemler kullanmaları ve çocukların etkileşimli oyunlar oynayabileceği ortamlar yaratmaları gerekmektedir. Öğretmenler çocukların sınıfta gün içerisinde kendilerini ifade edebilecekleri ortamlar yaratmaları ve açıklayıcı sözel ifadelerde bulunmaları çocukların sözcükleri daha kolay anlamaları ve kelime hazinelerini geliştirmeleri açısından önemli görülmektedir (Yazıcı ve Dereobalı, 2015). Bu yüzden öğretmenlerin çocukların kendilerini sözel olarak ifade edecekleri ortamlar yaratmaları çocukların dil gelişimleri açısından önem taşımaktadır. Okul öncesi dönem çocuklarının dil gelişimlerinin daha iyi olabilmesi için okul öncesi kurumlarında alınan eğitim önemlidir. Bu kurumlardaki çeşitli Türkçe dil etkinlikleri ve oyunlar ile çocukların dil gelişimleri olumlu yönde etkilenecektir (Demir, 2011). Öğretmenler çocukların dil becerilerini geliştirmek ve kelime sayılarını arttırmak için sınıf içerisinde çeşitli etkinlikler düzenlemeleri gerekmektedir (Karatay, 2007). 
Okul öncesi dönem eğitimi çocuğun anadili ve çevrenin kullandığı dilin gelişimi açısından önemli görülmektedir (Çakır, 2002). Okul öncesi eğitim sadece çocukların dil gelişimleri değil açısından bütün gelişim alanları açısından önem taşımaktadır. Gedikoğlu (2005)'na göre Türkiye'de okul öncesi eğitim üç-beş yaş aralığındaki zorunlu eğitim çağına gelmemiş çocuklara verilen eğitimdir. Bu eğitimle çocukların zihinsel, bedensel ve toplumsal gelişimi desteklenmekte ve çocukların yaratıcılıkları ortaya çıkartılmaktadır. Fakat Gedikoğlu (2005) Türkiye'de okul öncesindeki okullaşma oranının diğer ülkelere göre çok düşük olduğunu belirtmiştir.

Okul öncesi dönemde yapılan dil gelişimi alanı ile ilgili yapılan çalışmalar bu alanda daha iyi bir gelişimin sağlanması açısından önem taşımaktadır. Taner ve Başal (2005)'in 240 çocuk ile yaptıkları çalışma sonucunda okul öncesi eğitim alan çocukların dil gelişimlerinin okul öncesi eğitim almayan çocuklardan daha iyi olduğu ortaya çıkmıştır. Kandır ve Orçan (2009)'ın 162 çocuk ile yaptıkları çalışma sonucunda okul öncesine başlama yaşı düştükçe çocukların Dil ve Sayı Becerileri puanlarının arttığı gözlenmiştir. Akçay (2016)'ın 251 çocuk ve sekiz öğretmen ile yaptığı çalışma sonucunda okul öncesi eğitim alan çocukların dil gelişimlerinin almayan çocuklardan daha iyi olduğu ortaya çıkmıştır. Okul öncesi eğitimin çocukları ilkokula hazırladığı ve dil becerilerine de katkı sağladığı belirlenmiştir.

Lisansüstü eğitim, alınan en yüksek eğitim seviyesi olup, yüksek lisans ve doktora derecelerini kapsamaktadır. Türkiye'de lisansüstü eğitimlerde yapılan çalışmaların geliştirilmesi için de daha önceden yapılan çalışmaların önemi büyüktür (Karkın, 2011). Bilimsel araştırmalar diğer tüm alanlarda olduğu gibi okul öncesi alanında da büyük önem taşımaktadır. Okul öncesi eğitimde çalışmaların geliştirilmesi, yeni yapılacak çalışmalara yol gösterilmesi açısından lisansüstünde yapılan çaıışmaların incelenmesine intiyaç duyulmaktadır. Okul öncesi alanında yapılan çalışmalara bakıldığında okul öncesinde drama (Yaşar ve Aral, 2011), okul öncesinde oyun (Kaytez ve Durualp, 2014) ve okul öncesinde üstün yetenekli çocuklar (Koç ve Saranlı, 2017) ile ilgili yapılan lisansüstü tezlerin incelendiği çalışmalar olduğu görülmektedir. Okul öncesi dönemde dil gelişimi ile ilgili yapılan lisansüstü tezlerin incelenmesi ileride yapılacak olan lisansüstü tezlere ışık tutması açısından önemlidir.

\section{Araştırmanın Amacı}

İlgili literatür incelendiğinde okul öncesi alanında yapılmış olan lisansüstü tezlerinin incelenmesi konusunda çalışmaların olduğu görülmüştür (Yaşar ve Aral, 2011; Ahi ve Kıldan, 2013; Kaytez ve Durualp, 2014). Fakat okul öncesi dönem çocuklarının dil gelişimleri ile ilgili bütün alanlarda yapılan çalışmalar incelendiğinde okul öncesi dönem çocuklarının dil gelişimleri ile ilgili yapılan lisansüstü tezlerinin incelenmesi konusunda bir çalışmanın yapılmadığı belirlenmiştir. Türkiye'de okul öncesinde dil gelişimi alanında yapılan çalışmalara ihtiyaç duyulmaktadır. Bu araştırmada okul öncesinde dil gelişimi alanında yapılan lisansüstü tezlerin incelenmesi amaçlanmıştır. Bu çalışma dil gelişimi ile ilgili gerek okul öncesi alanında gerekse diğer alanlarda 0-6 yaş grubu çocuklarına yönelik olarak yapılacak çalışmalara katkı sağlaması açısından önemlidir. 
Rahime Filiz KIREMiT

\section{Araştırmanın Problemi}

Bu araştırmanın amacı, dil gelişimi ile ilgili yapılan lisansüstü tezlerin türleri, yıllara ve illere göre dağılımları, dilleri, bölümleri, üniversiteleri gibi genel karakteristik özelliklerinin yanı sıra lisansüstü tezlerin konularının, araştırma ve analiz tekniklerinin incelemesi amaçlanmıştır. 2000-2018 yılları arasında yapılmış olan lisansüstü tezlerin belirlenen ölçütler doğrultusunda analiz edilmesi ve mevcut durumlarının ortaya konulması amaçlanmıştır. "2000-2018 yılları arasında okul öncesinde dil gelişimi alanında yapılan yüksek lisans ve doktora tezlerinin özellikleri nelerdir?" amacı doğrultusunda dil gelişimi alanında üretilen lisansüstü tezlerin;

Genel karakteristik özellikleri nelerdir?

Konu dağılımı nasıldır?

Çalışma grubu dağılımı nasıldır?

Araştırma yöntemleri, veri toplama araçları ve analiz teknikleri nelerdir? Problemlerine yanıt aranmıştır.

\section{Yöntem}

\section{1. Araştırmanın Modeli}

Bu araştırma 2000-2018 yılları arasında yapılan lisansüstü tez çalışmalarının incelenmesi açısından betimsel tarama modelinde tasarlanmıştır. Betimsel araştırmalar çalışmaların dikkatli bir şekilde incelenmesini sağlar ve betimsel araştırmalarda en yaygın olan yöntem tarama modelidir (Büyüköztürk, Çakmak, Akgün, Karadeniz ve Demirel, 2008).

\subsection{Evren ve Örneklem}

Araştırmanın evrenini Yüksek Öğretim Kurumu Yayın Dokümantasyon Daire Başkanlığı tarafından 2000-2018 yılları arasında onaylanan ve arşivlenen, konu bölümü eğitim ve öğretim, dizin bölümü dil gelişimi olarak dizgilenen 88 lisansüstü eğitim tezi oluşturmaktadır. Bu araştırmada evreninin tümüne ulaşılmaya çalışılmıştır. YÖK Yayın Dökümantasyon Daire Başkanlığı sisteminde yer alan 88 lisansüstü tez incelendikten sonra izinsiz tezlere $(\mathrm{f}=24)$ tam metin olarak ulaşllamadığından bu tezler araştırma kapsamından çıkartılmıştır. Daha sonra özet kısımları incelenen lisansüstü tezlerden 0-6 yaş grubu çocuklarını kapsamayan tezler ( $\mathrm{f}=29)$ inceleme kapsamından çıkartılmıştır. Araştırma evreninin tamamına ulaşılamadığı için çalışma grubu 29 yüksek lisans ve 6 doktora tezi olmak üzere 35 lisansüstü tez çalışmasından oluşmaktadır.

\subsection{Veri Toplama ve Analiz}

Araştırma kapsamında öncelikle YÖK Yayın Dokümantasyon Daire Başkanlığı'nın internet sitesinde yer alan ulusal tez merkezi sayfasında eğitim ve öğretim konu alanında dil gelişimi dizininde 2000-2018 yıllarına yönelik arama yapılmıştır. Arama sonucunda ortaya çıkan 88 lisansüstü tez izinli ve izinsiz olmak üzere ayrımıştır. İzinli olan tezlerin özet kısımları incelenerek 0-6 yaş grubunun dil 
gelişimlerine yönelik olmalarına dikkat edilmiş ve bu tezler bilgisayar ortamına alınmıştır. Bunun sonucunda araştırmanın veri seti $\mathrm{f}=35$ tezden oluşmuştur. Bu tezlerin analizinde içerik analizi yöntemi kullanılmıştır. İçerik analizinde tez çalışmalarının yayınlandığı yıllar, uygulandığı iller, yapıldığı üniversiteler, yayınlandığı diller, bölümleri, çalışma grupları, konuları, tez çalışmalarında kullanılan araştırma modelleri ve analizinde kullanılan yöntemler dikkate alınmıştır. Değerlendirme sonucunda elde edilen veriler yüzde ve frekans dağılımları kullanılarak çözümlenmiştir.

\section{Bulgular ve Yorum}

Bu bölümde araştırma sonucunda elde edilen bulgular ve tablolar yer almaktadır.

\subsection{Genel karakteristik özellikleri}

Bu bölümde tez çalışmalarının yayınlandığı yıllar, uygulandığı iller, yapıldığı üniversiteler, yayınlandığı diller, bölümleri ve çalışma grupları gibi özellikler yer almaktadır.

Dil gelişimi alanında yapılan lisansüstü tezlerin yıllara göre dağılımları Tablo 1'de sunulmuştur.

Tablo 1. Lisansüstü Tezlerin Yıllara Göre Dağılımı

\begin{tabular}{|c|c|c|c|c|c|c|c|c|c|c|c|c|c|c|c|}
\hline \multicolumn{16}{|c|}{ Yillar } \\
\hline $\begin{array}{l}\text { Tezin } \\
\text { türü }\end{array}$ & రి & ষ্ণ & ర్ల & ¿্ర & 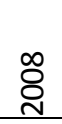 & $\stackrel{8}{\circ}$ & 음 & 공 & 공 & $\stackrel{n}{\stackrel{n}{0}}$ & 菅 & 囟 & $\begin{array}{l}0 \\
\text { 오 }\end{array}$ & 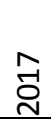 & $\begin{array}{l}\frac{\varepsilon}{\pi} \\
\frac{\pi}{0} \\
\frac{0}{0}\end{array}$ \\
\hline $\begin{array}{l}\text { Yüksek } \\
\text { lisans }\end{array}$ & 2 & 0 & 2 & 1 & 1 & 2 & 3 & 1 & 3 & 3 & 3 & 3 & 2 & 3 & 29 \\
\hline Doktora & 1 & 1 & 0 & 0 & 0 & 1 & 0 & 0 & 0 & 1 & 0 & 1 & 0 & 1 & 6 \\
\hline Toplam & 3 & 1 & 2 & 1 & 1 & 3 & 3 & 1 & 3 & 4 & 3 & 4 & 2 & 4 & 35 \\
\hline
\end{tabular}

Tablo 1'de görüldüğü gibi dil gelişimi alanında yapılan lisansüstü tez çalışmalarının \%82'sinin yüksek lisans tezi ( $f=29), \% 17$ 'sinin de doktora tezi $(f=6)$ olduğu görülmektedir. Yapılan yüksek lisans tezlerinin 2009 yılından sonra artmaya başladığı 2004 yılında ise dil gelişimi alanında yüksek lisans tezi yapılmadığı görülmüştür. 2004-2013 yılları arasında üçer yıl ara ile doktora tezi çalışmasının yapıldığı görülmüştür. Dil gelişimi alanında 2003 ve 2005 yıllarında hiç lisansüstü tez yapılmadığı ve genel olarak sınırlı sayıda doktora tezi çalışması yapıldığı görülmektedir.

Dil gelişimi alanında yapılan lisansüstü tezlerin illere göre dağılımları Tablo 2'de sunulmuştur. 
Rahime Filiz KIREMiT

Tablo 2. Lisansüstü Tezlerin Illere Göre Dağıımı

\begin{tabular}{|c|c|c|c|c|c|c|c|c|c|c|c|c|c|c|c|c|c|c|c|c|}
\hline \multicolumn{21}{|c|}{ iller } \\
\hline îli & $\begin{array}{l}\frac{\pi}{2} \\
\frac{\pi}{0} \\
\frac{0}{2}\end{array}$ & 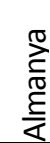 & 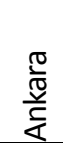 & $\frac{\frac{\pi}{2}}{\frac{\pi}{\pi}} \frac{1}{\frac{T}{4}}$ & 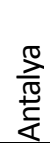 & 긍 & 总 & $\begin{array}{l}\frac{\bar{N}}{\bar{N}} \\
\bar{D}\end{array}$ & 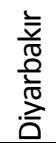 & $\begin{array}{l}\text { coc } \\
\frac{\pi}{W} \\
\frac{\pi}{W}\end{array}$ & 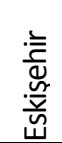 & 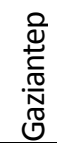 & $\begin{array}{l}\bar{\Xi} \\
\underline{\underline{n}} \\
\underline{\mathbb{n}} \\
\underline{\underline{n}}\end{array}$ & ह气 & 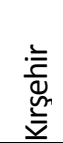 & $\begin{array}{l}\stackrel{0}{0} \\
\stackrel{0}{0}\end{array}$ & 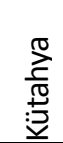 & 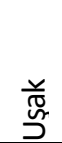 & $\begin{array}{l}\frac{\text { J }}{0} \\
\frac{0}{5} \\
\text { 00 } \\
\overline{0}\end{array}$ & $\frac{\frac{E}{\pi}}{\frac{0}{0}}$ \\
\hline $\begin{array}{l}\text { Yüksek } \\
\text { Lisans }\end{array}$ & 1 & 0 & 6 & 1 & 1 & 1 & 4 & 1 & 1 & 1 & 1 & 1 & 3 & 1 & 1 & 3 & 1 & 1 & 0 & 29 \\
\hline Doktora & 0 & 1 & 2 & 0 & 0 & 0 & 0 & 1 & 0 & 0 & 0 & 0 & 0 & 0 & 1 & 0 & 0 & 0 & 1 & 6 \\
\hline Toplam & 1 & 1 & 8 & 1 & 1 & 1 & 4 & 2 & 1 & 1 & 1 & 1 & 3 & 1 & 2 & 3 & 1 & 1 & 1 & 35 \\
\hline
\end{tabular}

Tablo 2'ye bakıldığında lisansüstü tezlerin sınırlı sayıda ilde yapıldığı görülmüştür. Tezlerin büyük çoğunluğunun Ankara ( $f=8$ ) ilinde sırası ile de Bursa $(f=4)$, İstanbul $(f=3)$, Konya $(f=3)$ gibi büyük şehirlerde yapıldığı görülmüştür. Yurtdışında (Almanya) yapılan bir adet doktora tezi bulunmaktadır. Adana, Antakya, Antalya, Bolu, Denizli, Diyarbakır, Elazığ, Eskişehir, Gaziantep, İzmir, Kütahya, Uşak ve Zonguldak illerinde de lisansüstü tezlerin yapıldığı görülmüştür.

Dil gelişimi alanında yapılan lisansüstü tezlerin dillere göre dağılımları Tablo 3'de sunulmuştur.

Tablo 3.Lisansüstü Tezlerin Dilleri

\begin{tabular}{llll}
\hline \hline Tezin türü & & & \\
\hline Dili & Türkçe & Ingilizce & Toplam \\
\hline Yüksek lisans & 26 & 3 & 29 \\
Doktora & 6 & 0 & 6 \\
\hline Toplam & 32 & 3 & 35 \\
\hline
\end{tabular}

Tablo 3'e bakıldığında lisansüstü tezlerinin \%91,43'ünün Türkçe ( $f=32$ ) yazıldığı, \%8,57'sinin de İngilizce ( $f=3$ ) yazıldığı görülmüştür. İngilizce yazılan yüksek lisans tezlerinin çok az sayıda olduğu $(\mathrm{f}=3)$, İngilizce yazılan doktora tezinin de bulunmadığı görülmüştür. 
Dil gelişimi alanında yapılan lisansüstü tezlerin bölümlere göre dağlımları Tablo 4'de sunulmuştur.

Tablo 4. Lisansüstü Tezlerin Bölümleri

\begin{tabular}{llll}
\hline \hline Tezin türü & & & \\
\hline Bölümü & Yüksek lisans & Doktora & Toplam \\
\hline Çocuk gelişimi & 5 & 1 & 6 \\
Dil ve konuşma terapistliği & 1 & 0 & 1 \\
Eğitim bilimleri & 1 & 0 & 1 \\
Özel eğitim & 3 & 1 & 4 \\
Psikoloji & 4 & 0 & 4 \\
Temel eğitim & 11 & 2 & 13 \\
Türkçe eğitimi & 3 & 1 & 4 \\
Yabancı diller & 1 & 1 & 2 \\
\hline Toplam & 29 & 6 & 35 \\
\hline
\end{tabular}

Tablo 4 incelendiğinde dil gelişimi alanında yapılan lisansüstü tezlerin çeşitli bölümlerde yapıldığı ortaya çıkmıştır. Çocuk gelişimi, dil ve konuşma terapistliği, eğitim bilimleri, özel eğitim, psikoloji, temel eğitim, Türkçe eğitimi, yabancı diller alanlardaki akademisyenlerin 0-6 yaş grubu ile çalıştıkları görülmüştür. Dil gelişimi alanında yapılan lisansüstü tezlerin \%37'sinin temel eğitim bölümünde $(f=13)$ yazıldığı görülmüştür. Tezlerin büyük çoğunluğunun çocuk gelişimi $(f=6)$, psikoloji(f=4), özel eğitim $(f=4)$ ve Türkçe eğitimi $(f=4)$ alanlarında yazıldığı görülmüştür. Dil ve konuşma terapistliği, eğitim bilimleri, yabancı diller alanında da birer tane lisansüstü tez çalışması yapıldığı görülmüştür.

Dil gelişimi alanında yapılan lisansüstü tezlerin üniversitelere göre dağılımları Tablo 5'de sunulmuştur.

Tablo 5. Lisansüstü Tezlerin Yapıldığı Üniversiteler

\begin{tabular}{lccc}
\hline \hline \multicolumn{1}{c}{ Üniversitesi } & $\begin{array}{c}\text { Yüksek } \\
\text { lisans }\end{array}$ & Doktora & Toplam \\
\hline Abant İzzet Baysal Üniversitesi & 2 & 0 & 2 \\
Anadolu Üniversitesi & 1 & 0 & 1 \\
Ankara Üniversitesi & 3 & 2 & 5 \\
Boğaziçi Üniversitesi & 1 & 0 & 1 \\
\hline
\end{tabular}




\begin{tabular}{llll}
\hline Çukurova Üniversitesi & 1 & 0 & 1 \\
Dicle Üniversitesi & 1 & 0 & 1 \\
Dokuz Eylül Üniversitesi & 2 & 0 & 2 \\
Fırat Üniversitesi & 1 & 0 & 1 \\
Gazi Üniversitesi & 1 & 1 & 1 \\
Hacettepe Üniversitesi & 1 & 1 & 1 \\
İstanbul Üniversitesi & 1 & 0 & 1 \\
Karadeniz Teknik Üniversitesi & 1 & 0 & 1 \\
Maltepe Üniversitesi & 1 & 0 & 1 \\
Marmara Üniversitesi & 0 & 1 & 1 \\
Mustafa Kemal Üniversitesi & 1 & 0 & 1 \\
Orta Doğu Teknik Üniversitesi & 2 & 0 & 2 \\
Pamukkale Üniversitesi & 3 & 1 & 4 \\
Selçuk Üniversitesi & 3 & 0 & 3 \\
Uludağ Üniversitesi & 2 & 0 & 2 \\
Yıldız Teknik Üniversitesi & 1 & 0 & 1 \\
\hline \multicolumn{1}{c}{ Toplam } & 29 & 6 & 35 \\
\hline
\end{tabular}

Tablo 5 incelendiğinde lisansüstü tezlerin büyük çoğunluğunun Ankara Üniversitesinde $(f=5)$, Pamukkale Üniversitesinde $(f=4)$ ve Selçuk Üniversitesinde $(f=3)$ yapıldığı ortaya çıkmıştır. İncelenen tezlerde Abant İzzet Baysal Üniversitesi $(f=2)$, Orta Doğu Teknik Üniversitesi $(f=2)$ ve Uludağ Üniversitesinde ( $f=2$ ) az sayıda çalışma yapıldığı, Anadolu Üniversitesi, Boğaziçi Üniversitesi, Çukurova Üniversitesi, Dicle Üniversitesi, Fırat Üniversitesi, Gazi Üniversitesi, Hacettepe Üniversitesi, İstanbul Üniversitesi, Karadeniz Teknik Üniversitesi, Maltepe Üniversitesi, Marmara Üniversitesi, Mustafa Kemal Üniversitesi, Yıldız Teknik Üniversitesi gibi üniversitelerde de birer tane lisansüstü tez çalışması yapıldığı görülmüştür.

Tezlerin yapıldığı üniversitelerin büyük üniversiteler oldukları görülmüştür. Tezlerin yazıldığı üniversitelerin türleri ele alındığında büyük çoğunluğunun kamu üniversitesi ( $f=34$ ) olduğu, sadece bir tane üniversitenin vakıf üniversitesi $(\mathrm{f}=1)$ olduğu belirlenmiştir.

\subsection{Konu Dağılımı}

Bu bölümde tezlerin konu dağılımlarına yer verilmiştir.

Dil gelişimi alanında yapılan lisansüstü tezlerin konularına göre dağılımları Tablo 6'da sunulmuştur. 
Tablo 6. Lisansüstü Tezlerin Konu Dağılımı

\begin{tabular}{lccc}
\hline \hline \multicolumn{1}{c}{ Konusu } & \multicolumn{3}{c}{ Tezin türü } \\
\hline Yabancı dil öğretiminin dil gelişimine etkisi & 2 & Doktora & Toplam \\
Dil gelişimi ve sosyal kabul arasındaki ilişki & 4 & 1 & 3 \\
Eğitim programlarının dil gelişime etkisi & 3 & 0 & 4 \\
Dil gelişimi ve ilkokula hazırlık & 1 & 1 & 4 \\
Kitapların dil gelişimine etkisi & 3 & 0 & 1 \\
Yaratıcı dramanın dil gelişimine etkisi & 1 & 2 & 5 \\
Annenin/bakııının dil gelişimi üzerindeki etkisi & 3 & 0 & 1 \\
Okul öncesi eğitimin dil geliş̧mine etkisi & 1 & 0 & 3 \\
Dil gelişiminin çeşitli açılardan incelenmesi & 4 & 0 & 1 \\
Medyanın dil gelişimine etkisi & 2 & 1 & 5 \\
Prematüre doğumun dil gelişimine etkisi & 1 & 0 & 2 \\
Özel eğitim gerektiren çocuklarda dil gelişimi & 4 & 0 & 1 \\
\hline \multicolumn{1}{c}{ Toplam } & 29 & 1 & 5 \\
\hline
\end{tabular}

Tablo 6'ya bakıldığında dil gelişimi alanında yapılan tezlerin konu alanlarının çeşitli oldukları görülmektedir. İncelenen tezlerin \%14'ünün kitapların dil gelişimine etkisi ( $f=5$ ), $\% 14$ 'ünün dil gelişiminin çeşitli açılardan incelenmesi $(\mathrm{f}=5)$, yine \%14'ünün özel eğitim gerektiren çocuklarda dil gelişimi $(\mathrm{f}=5)$, konularında oldukları görülmüştür. Hazırlanan eğitim programlarının dil gelişimine katkısı konusunun incelenen tezlerin \%11'ini oluşturduğu görülmektedir. Dil gelişiminin sosyal kabul ile ilişkisi de incelenen tezlerin \%11'ini oluşturmaktadır. Yabancı dil öğretiminin dil gelişimine etkisi ( $f=3)$, annenin ya da bakıcının dil gelişimi üzerine etkisi $(f=3)$, medyanın dil gelişimine etkisi $(\mathrm{f}=2$ ) gibi konularda da çalışıldığı görülmektedir. Daha az çalışılan konular ise dil gelişimi ve ilkokula hazırlık ( $f=1)$, yaratıcı dramanın dil gelişimine etkisi $(f=1)$, okul öncesi eğitimin dil gelişimine etkisi $(\mathrm{f}=1)$, prematüre doğumun dil gelişimine etkisi $(\mathrm{f}=1)$ gibi konulardır.

\subsection{Lisansüstü tezlerin çalışma grubu}

Bu bölümde tezlerin çalışma grubuna göre dağılımlarına yer verilmiştir.

Dil gelişimi alanında yapılan lisansüstü tezlerin çalışma grubuna göre dağıımları Tablo 7'de sunulmuştur.

Tablo 7. Lisansüstü Tezlerin Çalışma Grubu

\begin{tabular}{llll}
\hline \hline \multicolumn{1}{l}{ Tezin türü } & & \\
\hline Çalışma grubu & Yüksek lisans & Doktora & Toplam \\
\hline Çocuk & 17 & 4 & 21 \\
Çocuk annesi & 2 & 0 & 2
\end{tabular}




\begin{tabular}{llll} 
Çocuk ve anneleri & 3 & 0 & 3 \\
Çocuk ve babaları & 1 & 0 & 1 \\
Çocuk ve ailesi & 1 & 0 & 1 \\
Çocuk ve öğretmenleri & 1 & 1 & 2 \\
Çocuk, öğretmen ve ailesi & 1 & 1 & 2 \\
Öğretmen ve ailesi & 1 & 0 & 1 \\
Kitap & 2 & 0 & 2 \\
\hline Toplam & 29 & 6 & 35
\end{tabular}

Tablo 7 incelendiğinde araştırma kapsamındaki lisansüstü tezlerin \%60'nın çalışma grubu olarak çocuklarla ( $\mathrm{f}=21$ ) çalıştığı görülmüştür. İncelenen tezlere bakıldığında çalışma grubu olarak ailelerin ve öğretmenlerin çok az sayıda tercih edildiği ortaya çıkmıştır. Çocuk anneleri $(f=2)$, çocuk ve anneleri ( $f=3)$, çocuk ve öğretmenleri ( $f=2)$, çocuk, öğretmen ve ailesi $(f=2)$ ve kitap $(f=2)$ gibi çalışma gruplarının yanı sıra çocuk ve babaları $(f=1)$, çocuk ve ailesi $(f=1)$, öğretmen ve ailesi $(f=1)$ gibi çalışma grupları da lisansüstü tezlerde çalışma grubu olarak seçilmiştir.

\subsection{Lisansüstü tezlerin araştırma ve analiz teknikleri}

Bu bölümde tezlerin araştırma yöntemleri, veri toplama araçları ve analiz tekniklerine yer verilmiştir.

Dil gelişimi alanında yapılan lisansüstü tezlerin araştırma türlerine göre dağılımları Tablo 8'de sunulmuştur.

Tablo 8. Lisansüstü Tezlerin Araştırma Türleri

\begin{tabular}{lccc}
\hline \hline & \multicolumn{2}{c}{ Tezin türü } & \\
\hline Araştırmanın yöntemi & Yüksek lisans & Doktora & Toplam \\
\hline Tarama modeli & 4 & 1 & 5 \\
ilişkisel tarama modeli & 7 & 0 & 7 \\
Betimsel model & 5 & 1 & 6 \\
Deneysel model & 6 & 1 & 7 \\
İçerik analizi & 1 & 1 & 2 \\
Özel durum çalışması & 1 & 1 & 2 \\
Tümevarım analiz yöntemi & 1 & 0 & 1 \\
Doküman incelemesi & 1 & 0 & 1 \\
\hline
\end{tabular}


Eskişehir Osmangazi Üniversitesi Sosyal Bilimler Dergisi

\begin{tabular}{llcc}
\hline Karma yöntem & 3 & 1 & 4 \\
\hline Toplam & 29 & 6 & 35 \\
\hline
\end{tabular}

Tablo 8 incelendiğinde araştırma kapsamındaki lisansüstü tezlerinin \%20'sinin ilişkisel tarama modelinde $(f=7)$ ve $\% 20$ 'sinin de deneysel modelde $(f=7)$ yapılan çalışmalar olduğu görülmektedir. Bu çalışmaları \%17 ile betimsel model $(f=6)$ ve \%14 ile tarama modeli $(f=5)$ takip etmektedir. Bu sonuçlara bakılarak nitel araştırma modellerinin nicel araştırma modellerine göre daha çok tercih edildikleri görülmüştür. Yapılan çalışmaların \%11'inin de karma desende tasarlanan ( $f=4)$ çalışmalar olduğu görülmüştür. Tümevarım analiz yöntemi $(f=1)$ ve doküman incelemesi $(f=1)$ yöntemlerinin de az sayıda lisansüstü tezde kullanıldığı belirlenmiştir.

Dil gelişimi alanında yapılan lisansüstü tezlerin veri toplama araçlarına göre dağılımları Tablo 9'da sunulmuştur.

Tablo 9. Lisansüstü Tezlerde Kullanılan Veri Toplama Araçları

Tezin türü

\begin{tabular}{cccc}
\hline Veri toplama araçları & Yüksek lisans & Doktora & Toplam \\
\hline Anket & 1 & 0 & 1 \\
Doğal konuşma örneği & 3 & 0 & 3 \\
Doküman & 2 & 0 & 2 \\
Görüşme formu & 4 & 0 & 4 \\
Görüşme ve gözlem & 0 & 1 & 1 \\
Ölçek & 19 & 3 & 22 \\
Ölçek ve doğal konuşma Örneği & 0 & 2 & 2 \\
\hline Toplam & 29 & 6 & 35 \\
\hline
\end{tabular}

Tablo 9 incelendiğinde incelenen tezlerin \%63'ünün veri toplama araçlarından ölçek ( $f=22$ ) kullandığı, \%11'nin de görüşme formu ( $f=4)$ kullandığı görülmüştür. Tezlerde doğal konuşma örneği alınması $(f=3)$, ölçek ve doğal konuşma örneği alınmasının bir arada kullanılması ( $f=2)$, dokümanlar yolu ile veri toplanması $(f=2)$, anket kullanımı $(f=1)$, görüşme ve gözlemin bir arada kullanımı $(f=1)$ gibi veri toplama araçlarının da az sayıda kullanıldığı görülmüştür.

Dil gelişimi alanında yapılan lisansüstü tezlerin veri analiz yöntemlerine göre dağılımları Tablo 10 'da sunulmuştur. 
Rahime Filiz KIREMiT

Tablo 10. Lisansüstü Tezlerde Kullanılan Veri Analiz Yöntemleri

\begin{tabular}{cccc}
\hline \hline \multicolumn{1}{c}{ Tezin türü } & & & \\
\hline Veri analiz yöntemleri & $\begin{array}{c}\text { Yüksek } \\
\text { Llsans }\end{array}$ & Doktora & Toplam \\
\hline Betimsel istatistik (yüzde, frekans, aritmetik & 5 & 2 & 7 \\
ortalama) & 5 & 1 & 6 \\
İçerik analizi & 1 & 1 & 2 \\
Korelasyon & 4 & 0 & 4 \\
Mann Whitney-U Testi & 2 & 1 & 3 \\
Ön test-son test & 6 & 0 & 4 \\
t-testi & 3 & 1 & 3 \\
t-testi ve varyans analizi & 3 & 0 & 35 \\
Varyans analizi & 29 & 6 & \\
\hline Toplam & & & \\
\hline
\end{tabular}

Tablo 10 incelendiğinde araştırma kapsamındaki lisansüstü tezlerin \%20'sinin betimsel istatistik yöntemlerini ( $f=7$ ) kullandıkları belirlenmiştir. Tezlerin \%17'sininde T-testi $(f=6), \% 17$ 'sininde de içerik analizi yöntemleri $(\mathrm{f}=6)$ kullanımıştır. T-testi ve varyans analizinin $(\mathrm{f}=4)$ birlikte kullanıldı̆̆ı yöntemler ise tezlerin \%11'ini, Mann Whitney- $U$ testi $(f=4)$ de tezlerin \%11'ini oluşturmaktadır. Tezlerde ön test- son test $(f=3)$, korelasyon $(f=2)$, varyans analizi $(f=3)$ gibi yöntemlerin de kullanıldığı görülmüştür.

\section{Sonuç ve Öneriler}

Okul öncesi eğitimin, dil gelişimi, motor gelişim, sosyal ve duygusal gelişim, yaratıcılık, drama, matematik gibi çeşitli alanlarda çalışma yapılabilmesi için geniş bir çalışma sahasına sahip olduğu söylenebilir. Okul öncesinde dil gelişimi alanında yapılan çalışmaların bu alanlarda çalışacak olan öğretim üyeleri açısından yol gösterici olması beklenmektedir. Bu bağlamda okul öncesinde dil gelişimi alanında yapılan lisansüstü tezlerin incelenmesi önem arz etmektedir.

Bu çalışmada 2000-2018 yılları arasında dil gelişimi alanında yapılan lisansüstü tezlerin incelenmesi amaçlanmıştır. Bu amaç doğrultusunda incelenen tezler 0-6 yaş grubunda dil gelişimiyle sınırlı tutulmuştur. 0-6 yaş döneminde dil gelişimi bireylerin sağlıklı bir şekilde dili öğrenmeleri için önemli görülmektedir. Bu dönemdeki dil gelişimi için ailelere ve öğretmenlere de büyük görevler düşmektedir.

Yapılan incelemeler sonucunda 0-6 yaş dönemi dil gelişimi konusunda yapılan lisansüstü tezlerde doktora tezlerinin çok az sayıda olduğu görülmüştür. Coşkun, Dündar ve Parlak (2014)'a göre, doktora eğitiminin yüksek lisans eğitimine göre daha zahmetli ve giriş koşullarının da zor olması doktora alanında yapılan çalışmaların sayısını olumsuz yönde etkilemektedir. Doktora tezlerinin sayılarının arttırılması için danışmanların doktora öğrencilerini okul öncesinde dil gelişimi alanında 
yönlendirmeleri gerekmektedir. Ayrıca okul öncesi alanında doktora programlarının sayılarının arttırılması da doktora tezlerinin sayılarının artmasını olumlu yönde etkileyecektir.

Lisansüstü tezlerin yıllara göre dağılımlarına bakıldığında düzensiz bir dağılım olduğu görülmektedir. 2003 ve 2005 yıllarında okul öncesinde dil gelişimi alanında hiçbir çalışmanın yapılmadığı görülmektedir. Yapılan çalışmaların yıllara göre dağılımlarında da bazı yıllarda doktora çalışmalarının yapılmadığı belirlenmiştir. Bu alanda çalışan danışanların öğrencilerini yönlendirmeleri alana katkı sağlanması açısından önemlidir. İncelenen tezlerin büyük çoğunluğunun Ankara, İstanbul ve Konya gibi illerde yapıldığı görülmektedir. Sözü edilen bu illerde doktora programlarının olması bu illerdeki sayının artmasına sebep olmuş olabilir. Bu sebeple diğer illerdeki üniversitelerde de okul öncesi eğitimi doktora programlarının açılması ve öğrencilerinin bu alanlarda doktora eğitimi yapmaları teşvik edilebilir.

Tezlerin yazım dillerine bakıldığında çok az sayıda lisansüstü tezin İngilizce olarak yazıldığı görülmektedir. İngilizce olarak yazılan tezlerin de yüksek lisans tezler oldukları belirlenmiştir. Doktora tezlerinde yoğunlaşılan dilin Türkçe olması tezlerin uluslararası düzeyde okunabilirliğini ve akademisyenlerin bilime olan katkılarını olumsuz yönde etkileyeceği söylenebilir. Bu sebeple okul öncesi alanda yapılacak olan doktora tezlerinin İngilizce dilinde yazılmasının akademik ve bilimsel olarak önemli katkılar sağlayacağı söylenebilir.

0-6 yaş grubu dil gelişimine yönelik tezlerin üniversitelerin çeşitli bölümleri tarafından hazırlandığı görülmektedir. Sadece temel eğitim alanında değil, psikoloji, özel eğitim ve Türkçe eğitimi alanında da 0-6 yaş dönemine ait tezlerin yayınlandığı ortaya çıkmıştır. Diğer alanlarda da lisansüstü tezlerin yapılması okul öncesi dönemin bütün alanları kapsayan bir dönem olduğunu göstermektedir. Tezlerin yayınlandığı üniversitelere bakıldığında ise sadece belirli üniversiteler oldukları görülmüştür. Bunun sebebi olarak bu üniversitelerin köklü üniversiteler olması gösterilebilir. Yeni kurulan üniversitelerde çalışan öğretim üyelerinin yüksek lisans ve doktora öğrencilerini okul öncesi alanda çalışmaya teşvik etmeleri önerilebilir.

Incelenen tezlerin konu dağılımlarına bakıldığında 0-6 yaş dil gelişiminin çeşitli değişkenler açısından incelendiği görülmektedir. Hazırlanan eğitim programlarının dil gelişimlerine etkisi konusunda belirli sayıda tez çalışması olmasına rağmen, bu konuda sayının yeterli olmadığı düşünülmektedir. İncelenen lisansüstü tezlerde çalışma grubu olarak genellikle çocukların tercih edildiği görülmüştür. Çalışma grubu olarak aileler ve öğretmelerle çok az sayıda çalışma yapılmıştır. Akademisyenlerle ilgili bu konuda bir çalışma yapılmadığı da görülmüştür. Yapılan çalışmalara bakıldığında çalışmaların \%34,29'unda ailelerin çalışmalara dahil edildiği görülmektedir. Bitetti ve Scheffner Hammer (2016)'ın da belirttiği gibi dil gelişiminde ailelerin önemi büyüktür. Tamis-LeMonda, Shannon, Cabrera ve Lamb (2004) yaptıkları çalışmada aile ilişkilerinin çocukların dil gelişimleri üzerindeki etkisi incelenmiştir. Yapılan çalışma sonucunda ailelerin özellikle de babaların çocukların dil gelişimlerini etkiledikleri belirlenmiştir. Yapılan bu çalışmaya benzer olarak Karaca, Gündüz ve Aral (2011) da çocukların dil gelişimlerinde ve çocukların akranlarıyla olan iletişimlerinde ailelerin etkili olduğunu belirlemişlerdir. Ailelerin çocukların dil gelişimlerinde etkili olduğu görülmekte ve 
Rahime Filiz KIREMiT

ailelerle ilgili yapılacak olan çalışmaların da okul öncesi alanına katkı sağlayacağı düşünülmektedir. Yapılacak olan lisansüstü tez çalışmalarında ailelerinin dahil edilmesine özen gösterilmesi gerekmektedir.

Tezlerde kullanılan araştırma türlerine bakıldığında nitel çalışmaların daha fazla olduğu göze çarpmaktadır. En çok kullanılan modeller ise tarama ve ilişkisel modelleridir. Bunun yanı sıra araştırmacıların nitel ve nicel modellerin bir arada kullanıldığı karma yöntemi de tercih ettikleri görülmüştür. Karma yöntem, nitel ya da nicel çalışmaların tek başına yeterli olmadığı durumlarda kullanılmaktadır (Fırat, Yurdakul \& Ersoy, 2014). Araştırmacıların her iki yöntemi de kullanılması okul öncesi dönem çocukları hakkında hem ölçek kullanma hem de gözlem yapma imkanı sağlamaktadır. Bu sayede okul öncesi dönem çocukları hakkında daha çok bilgi edinilmekte ve çalışma sonuçları daha güvenilir olmaktadır.

Incelenen tezlerde kullanılan veri toplama araçları incelendiğinde araştırmacıların daha çok ölçek kullanmayı tercih ettikleri belirlenmiştir. Tezlerde veri toplama aracı olarak doğal konuşma örneği alınmasının az sayıda araştırmacı tarafından tercih edildiği görülmüştür. Doğal konuşma örneği, çocukların doğal ortamlarında söyledikleri cümleler kayıt altına alındıktan sonra yapılan hesaplamaları kapsamaktadır (Ege, Acarlar \& Güleryüz, 1998). 0-6 yaş grubunda doğal konuşma örneği alınmasının çocukların dil gelişimlerini konusunda daha net bilgi vereceği düşünülmektedir. Incelenen tezlerde kullanılan analiz yöntemlerine bakıldığında betimsel istatistik yöntemleri, t-testi ve içerik analizi yöntemlerinin daha çok kullanıldığı görülmektedir. Sonuç olarak okul öncesinde dilgelişimi alanında yapılan çalışmaların alanın geliştirilmesinde yeterli olmadığı düşünülmektedir. Bu alanda daha fazla çalışma yapılması eğitimcilere, anne babalara ve öğretmenlere yarar sağlayacaktır.

Yukarıda tespit edilen sonuçlar doğrultusunda; dil gelişimi alanında yapılacak olan doktora tezlerine öncelik verilmesi, tezlerin yapıldığı iller göz önünde bulundurulduğunda belirli illerde çalışmalar yapıldığı sonucundan hareketle, uygulanacak olan tezlerin çeşitli illere yayılması konusuna dikkat edilmesi, tezlerin çalışma grubu olarak çocuklar dışında çocukları aileleri, öğretmenleri ya da akademisyenlerle yapılacak olan çalışmalara öncelik verilmesi, veri toplama araçlarının çeşitliliğin sağlanması, dil gelişimi alanında daha kapsamlı ve farklı türlerde çalışmaların yapııması gibi öneriler getirilebilir.

\section{Kaynaklar}

Ahi, B. ve Kıldan, A. O. (2013). Türkiye'de okul öncesi eğitimi alanında yapılan lisansüstü tezlerin incelenmesi (2002-2011). Mehmet Akif Ersoy Üniversitesi Eğitim Fakültesi Dergisi, 1(27), 2346.

Akçay, A. (2016). Okulöncesi eğitimi almanın öğrencilerin dil becerilerinin gelişimine etkisi. International Periodical for the Languages, Literature and History of Turkish or Turkic. 11(3). 15-28. 
Ayrancı, B.B. (2018). 0-12 yaş dil gelişimi uygulamaları ve yapılması gerekenler. Kırıkkale Üniversitesi Sosyal Bilimler Dergisi 8(1),13-34.

Bitetti, D. \& Scheffner Hammer, C. (2016). The home literacy environment and the English narrative development of Spanish-English bilingual children. Journal of Speech, Language, and Hearing Research, 59(5), 1159-1171.

Büyüköztürk, Ş., Çakmak, E. K., Akgün, Ö. E., Karadeniz, Ş. ve Demirel, F. (2008). Bilimsel araştırma yöntemleri. (2. Baskı). Ankara: PegemA Akademi.

Çakır, M. (2002). Almanya'daki çok kültürlü ortamlarda Türkçenin anadili olarak kullanımı. Anadolu Üniversitesi Sosyal Bilimler Dergisi, https://earsiv.anadolu.edu.tr/xmlui/handle/11421/518 sayfasından erişilmiştir.

Coşkun, İ., Dündar, Ş., ve Parlak, Ş. (2014). Türkiye'de Özel Eğitim Alanında Yapılmış Lisansüstü Tezlerin Çeşitli Değişkenler Açısından İncelenmesi. Ege Eğitim Dergisi. 2(15). 375-396.

Çelebi, M. D. (2006). Türkiye'de anadili eğitimi ve yabancı dil öğretimi. Erciyes Üniversitesi Sosyal Bilimler Enstitüsü Dergisi. 1(21). 285-307.

Demir, S. (2011). Okul öncesi dönemde dil gelişimi ve sorunları. Türkçe Araştırmaları Akademik Öğrenci Dergisi. 1(1). 38-49.

Demirezen, M. (2003). Yabancıl dil ve anadil öğreniminde kritik dönemler. TÖMER Dil Dergisi. 1(18). 5-15.

Ege, P., Acarlar, F., ve Güleryüz, F. (1998). Türkçe kazanımında yaş ve ortalama sözce uzunluğunun etkisi. Türk Sosyoloji Dergisi. 13(41). 19-31.

Fırat, M., Yurdakul, I., ve Ersoy, A. (2014). Bir eğitim teknolojisi araştırmasına dayalı olarak karma yöntem araştırması deneyimi. Eğitimde Nitel Araştırmalar Dergisi. 2(1). 65-86.

Gedikoğlu, T. (2005). Avrupa birliği sürecinde Türk eğitim sistemi: Sorunlar ve çözüm önerileri. Mersin Üniversitesi Eğitim Fakültesi Dergisi. 1(1). 66-80.

Huber, E. (2007). Bildirişim edincinin dil edincine etkisi. Dil Dergisi. 1(35). 7-21.

Kandır, A. ve Orçan, M. (2009). Alt ve üst sosyo-ekonomik düzeydeki ailelerin beş-altı yaş çocuklarının erken öğrenme becerilerinin bazı değişkenler yönünden incelenmesi. Kuramsal Eğitimbilim Dergisi. 2(1). 1-13.

Karaca, N.H., Gündüz, A., ve Aral, N. (2011). Okul öncesi dönem çocuklarının sosyal davranışının incelenmesi. Kuramsal Eğitimbilim Dergisi. 4(2). 65-76.

Karatay, H. (2007). Kelime öğretimi. Gazi Üniversitesi Gazi Eğitim Fakültesi Dergisi. 27(1). 141-153.

Karkın, M.A. (2011). Müzik bilimleri alanında yapılan lisansüstü tezlerin incelenmesi. İnönü Üniversitesi Sanat ve Tasarım Dergisi. 1(2). 143-149. 
Rahime Filiz KIREMiT

Kaytez, N., Durualp, E. (2014). Türkiye'de okul öncesinde oyun ile ilgili yapılan lisansüstü tezlerin incelenmesi. Uluslararası Türk eğitim bilimleri dergisi. 2(2). 110-122.

Koç, F., Saranlı, A.G. (2017). Erken çocukluk dönemindeki üstün yetenekli çocuklara ilişkin Türkiye'deki lisansüstü çalışmaların çok boyutlu analizi. Mehmet Akif Ersoy Üniversitesi Eğitim Fakültesi Dergisi. 1(41). 163-183.

Lee, J.S., Choi, J.Y., \& Marqués-Pascual, L. (2016). An analysis of communicative language functions in the speech patterns of bilingual Korean and Mexican immigrant children. Journal of New Approaches in Educational Research, 5(2), 66-73.

Marsh, D. (2012). Content and language integrated learning (CLIL): A development trajectory. Córdoba, Spain: University of Córdoba

McDevitt, M.T., Ormrod, E.J. (2013). Child development and education. Pearson: New Jersey.

Morrison, G.S. (2015). Early childhood education today. Pearson: New Jersey.

MEGEP (2007). Çocuk gelişimi ve eğitimi- Dil gelişimi. Mesleki Eğitim ve Öğretim

Milli Eğitim Bakanlığı (2013). Okul öncesi eğitim programı. Ankara, MEB.

Özbay, M. ve Melanlıoğlu, D. (2008). Türkçe eğitiminde kelime hazinesinin önemi. Yüzüncü Yıl Üniversitesi Eğitim Fakültesi Dergisi, 5(1), 30-45.

Tamis-LeMonda, C. S., Shannon, J. D., Cabrera, N. J. \& Lamb, M. E. (2004). Fathers and mothers at play with their 2 and 3 year olds: Contributions to language and cognitive delevopment. Child Development. 75(6). 1806-1820.

Taner, M. ve Başal, H. A. (2005). Farklı sosyoekonomik düzeylerde okulöncesi eğitimi alan ve almayan ilköğretim birinci sınıf öğrencilerinin dil gelişimlerinin cinsiyete göre karşılaştırılması. Uludağ Üniversitesi Eğitim Fakültesi Dergisi. 18(2). 395-420.

Temel, F. (2009). 0-6 Yaş çocuklarında dilin kazanılması. Çukurova Üniversitesi-Türkoloji. Sisteminin Güçlendirilmesi Projesi. Ankara.

Temel, F., Bekir, H. ve Yazıcı, Z. G. (2014). Erken çocuklukta dil edinimi. Ankara: Vize Yayınclık.

Yaşar, C.M. ve Aral, N. (2011). Türkiye'de okul öncesinde drama alanında yapılan lisansüstü tezlerin incelenmesi. Mehmet Akif Ersoy Üniversitesi Eğitim Fakültesi Dergisi. 11(22). 70-90.

Yazıcı, Z. ve Dereobalı, N. (2015). Sözel dil becerisi ve erken okuryazarlık. Z.F. Temel (Ed.), Dil ve erken okuryazarlık içinde (s. 34-59). Ankara: Hedef CS Yayıncılık. 